Зіновій Коваль

дочент кафедри державознавства і права

ОРІДУ НАДУ при Президентові України, к.держ. упр.

\title{
ІНФОРМАЦІЙНО-ПСИХОЛОГІЧНА СТІЙКІСТЬ ОСОБИСТОСТІ ТА СОЦІУМУ В ЛІТЕРАТУРІ: АНАЛІЗ ДОСЛІДЖЕНЬ ТА ПУБЛІКАЦІЙ
}

Публікація присвячена аналізу малодосліденої теми інформащійно-психологічної стійкості особистості, сочіуму в інформащійну епоху. Проаналізовано деякі підходи до характеристики явища психологічної стійкості. Запропоновано в інформаційну епоху характеризувати стан інформаційно-психологічної стійкості.

Ключові слова: психологічна стійкість; емоційна стійкість; інформаційно-психологічна стійкість,інформаційна епоха; управлінські процеси; норми права.

\section{Zinoviy Koval}

Associate Professor of Law and Legislative Process Department of the

ORIPA NAPA under the President of Ukraine, PhD in Public Administration

\section{THE INFORMATION AND PSYCHOLOGICAL RESILIENCE OF A PERSON AND SOCIETY IN THE LITERATURE: THE ANALYSIS OF RESEARCHES AND PUBLICATIONS}

The publication is devoted to the analysis of a little researched subject of the information-psychological resilience of a person and society in the information age. Some approaches to the characteristics of a psychological stability are studied. The author proposes to characterize such situation as the situation of an information-psychological resilience.

Formulation of the problem in general. The subject of the information-psychological resilience of a person, society and country in the information age is poorly researched, though it is crucially important to the national security, especially in conditions of undeclared hybrid war against Ukraine. And the informational war takes on enormous importance in this hybrid war.

Analysis of recent research and publications. This problem is partly studied in the publications of Ukrainian scientists Y. Amynyeva, T. Andreyeva, I. Arshava, E.Nosenko, V. Belyumov, M. Kostenko, T. Mazur; and foreign ones - B. Bernard, S. Kobasa, S.Muddy, M. Balandyna, V. Zaporozhnenko, A. Leontyev, D. Leontyev, A. Maklakov, L. Mytyna, G. Nykyforova, T. Rohacheva, V. Chudnovskyi.

Bold unsolved aspects of the problem. The unitary approaches to a thorough study of the information-psychological resilience of a person, society and country have not yet been elaborated; the criteria for evaluations are not defined. The very category of the information-psychological resilience has not been studied enough.

The purpose of the article. The purpose of this publication is to outline the conceptual approaches to charachteristics of the information-psychological resilience of a person, society and country.

Key words: psychological stability; emotional stability; information-psychological resilience; information age; management processes; rules of laz.

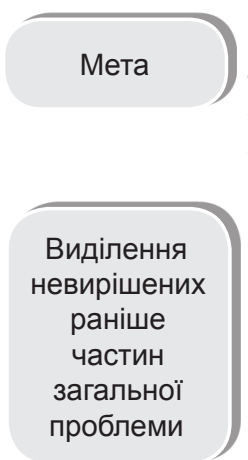

Метою даної публікації $є$ окреслення концептуальних підходів до характеристики інфрормаційно-психологічної стійкості людини, соціуму, держави.

Єдині підходи до ґрунтовного вивчення явища інформаційно-психологічної стійкості людини, соціуму, держави все ще не напрацьовані, критерії оцінок не визначені. Сама категорія інформаційно-психологічної стійкості мало досліджена.

Даній проблематиці частково

Аналіз

останніх досліджень і публікацій присвячено публікації українських науковців - Я. Амінєвої, Т. Андреєвої, І. Аршави, Е. Носенко, В. Белюмова, М. Костенко, Т Мазур, закордонних - Б. Бернард, Сюзен Кобейса,

Сальвадора Мадді, М. Баландіна, В. Запорожненко, А. Леонтьєва, Д. Леонтьєва, А. Маклакова, Л. Мітіна, Г. Нікіфорова, Т. Рогачева, В. Чудновського.
Постановка проблеми

Тема інформаційно-психологічної стійкості особи, соціуму, держави в інформаційну епоху не пропрацьована і малодосліджена, хоча критично важлива для національної безпеки, особливо в умовах, коли проти України ведеться неоголошена гібридна війна, центральне місце в якій відводиться війні інформаційній.

Вивчення проблеми психологічної
Виклад

основного

матеріалу стійкості в нових умовах інформаційної епохи отримало особливу актуальність, оскільки сучасні соціальні, політичні та економічні зміни швидкоплинні й часом непередбачувані. Особливо психологічна стійкість необхідна у сфері державного управління та публічного адміністрування.

Для розуміння феномену психологічної стійкості важливе значення мають теоретичні концепції про психологічні явища, що неусвідомлені суб'єктивно (А. Адлер, 3. Фрейд, К. Г. Юнг, Е. Е. Фром). Проблема стій- 
кості процесів вищої нервової діяльності вивчалась І. М. Сеченовим, В. М. Бехтеревим, І. П. Павловим Уперше проблема психологічної стійкості предметно поставлена в доповіді Л. І. Божович на ХУІІІ Психологічному конгресі у 1966 році. Подальший розвиток тематики психологічної стійкості отримав у дослідженнях, що розглядають різні аспекти цієї проблеми: емоційна стійкість (П. Б. Зільберман, В. А. Маріщук, Л.В. Мітіна), моральна стійкість (В. Е. Чудновський), стійкість форм поведінки (Л. І. Божович), стійкість в складних умовах (К. М. Гуревич, А. А. Леонов, Г. Т. Берегова).

Психологічна стійкість - це базова характеристика особистості, становлення якої залежить від мотивів, обумовлених обставинами, та їх переходу в нову стійку якість, що характеризуватиме дану особистість.

У дослідженнях наукової школи Д. Н. Узнадзе психологічна стійкість виступає у вигляді ієрархізованої багаторівневої установочної структури, яка забезпечує психологічний механізм стабілізації діяльності людини [8].

Стійкість у дослідженнях В. Е. Чудновського розглядається як моральна категорія, що має свій імунітет до різного роду впливів, які суперечать особистісним установкам, поглядам та переконанням. Стійкість виступає як результат активної життєдіяльності та самоорганізації. Стійкість особистості розглядається як здатність людини зберігати свої особистісні позиції та протидіяти деструктивним впливам, разом із можливістю реалізувати свої особисті погляди [20].

О. М. Леонтьєв вважає, що структура особистості представляє собою відносно стійку конфрігурацію головних, у середині себе, ієрархізованих, мотиваційних ліній. Багатогранні діяння людини пересікаються між собою та зв'язуються у вузли об'єктивними, суспільними за своєю природою відносинами, у які вони вступають. Ці вузли ієрархії формують той таємничий «центр особистості», який ми називаємо «Я», і центр цей знаходиться не в індивіді, а в його бутті». Тому егоцентричне «Я» включено у взаємозвязок особистостей, колективу, громади, соціуму [11].

Емоційну стійкість вчені розглядають як складну інтегративну якість особистості, яка характеризується комплексом емоційних, вольових, моральних, інтелектуальних компонентів психічної діяльності, як системну якість особистості її здатність протидіяти емоційним подразнювачам. Так, Л. М. Мітіна розглядає проблему емоційної стійкості як здатність людини протидіяти різного роду життєвим труднощам без втрати психологічної адаптації [15].

В інформаційну епоху однією з найхарактерніших особливостей сучасного життя $€$ ніщо інше, як підвищений інформаційно-психологічний вплив на людину, суспільство, державу. Тому, на думку автора, нині доречно говорити не стільки про психологічну стійкість, як про її нову якість - інформаційно-психологічну стійкість. В нових інформаційних обставинах психологічна стійкість являє собою процес збереження найбільш оптимального режиму роботи психіки людини і соціуму в умовах постійно мінливих обставин і їх стресового впливу. Властивість інформаційно-психологічної стійкості особистості формується у людини в процесі іiї розвитку і не $є$ генетично обумовленою. До того ж, сама психологічна стійкість - це не стовідсоткова гарантія стійкості взагалі до всього. Психологічна стій- кість $€$ скоріше гнучкістю психіки людини, ніж непохитністю і стабільністю її нервової системи.

За висновком Т. В. Мазур, М. Є. Лещенко, Ю. В. Орешети, єдиної думки у визначенні сутності феномена психологічної стійкості, його психологічних механізмів і чинників формування у дослідників поки що немає. В ситуації, коли суспільство майже щодня переживає потрясіння за потрясінням, живе у нав'язаному інформаційному негативі, з'являється необхідність розробки нової концепції психологічної стійкості, так як саме психологічна стійкість дозволяє на довгостроковій основі забезпечувати функціонування особистості, не приводячи до деградаційних процесів [13]. Саме тому нова концепція психологічної стійкості повинна бути концепцією інфрормаційно-психологічної стійкості, адже суспільні потрясіння транспортуються інформаційним шляхом.

Особливістю підвищення інформаційно-психологічної стійкості людини та соціуму є прийняття того беззаперечного фракту, що коли людина та соціум не здатні змінити об'єктивні обставини, але вони в силах змінити своє ставлення до них. Це особливо характерно для управлінських процесів. На підвищення інформаційно-психологічної стійкості безпосередньо впливають умови, в яких перебуває людина та соціум. Вміння систематично розвантажувати свою нервову систему - це один із основних спосіб підвищити свою психологічну стійкість. Позитивно вплинути на це може тільки повноцінний відпочинок та фрілософське ставлення до життя. Психічне здоров'я людини та соціуму тісно взаємопов'язане і з такими якостями, як гумор, позитивне мислення, вміння посміятися над собою, самокритичність. Але й тут необхідна межа, за якою йдуть негативні процеси заниженої самооцінки, невпевненості, ослаблення волі до спротиву.

Важливим ефективним методом для фрормування інформаційно-психологічної стійкості є позитивний образ самого себе і самих себе, свого трудового колективу. Але потрібно бути обережним і не перейти чергову межу, що призводить до саможалю і сприйняттю світу з позиції вічної жертви, інакше психологічна нестійкість тільки посилиться. Особливо потрібен інфрормаційно-психологічний позитив у ЗМІ. На жаль, українська дійсність роботи демократичних ЗМІ продукує значно більше негативу, ніж позитиву. Читацькі та глядацькі аудиторії привчають жити в інформаційно-психологічному негативі, чим підриваються основи інформаційно-психологічної стійкості людини та соціуму. Вихід 3 такої ситуації лежить саме в правовому полі, де нормами права ця проблема повинна бути врегульована.

Категорія «стійкість» перейшла в психологію з технічних наук, де основним показником стійкості системи вважається її здатність відчувати зовнішні впливи без руйнування, тобто без переходу не просто в інший стан, а в такий, коли система перестає бути сама собою. У великому психологічному словнику А. Ребера під стійкістю розуміється «характеристика індивіда, поведінка якого надійна і послідовна» [18]. Антонімом поняття «стійкість» виступає поняття «нестійкість», яка, в свою чергу, характеризується безладними і непередбачуваними моделями поведінки і настрою та демонструванням невротичних, психотичних і просто непродуктивних моделей поведінки.

3 метою розуміння справжньої природи явища психологічної стійкості особистості, необхідно розглядати 
іiї, з одного боку, в контексті цілісної поведінки індивіда, а з іншого - в аспекті відносної самостійності складових його компонентів і рівнів. Із цих позицій психологічну стійкість можна розглядати як особливу організацію існування особистості як системи, яка забезпечує максимально ефективне функціонування більш складної системи «людина - соціум» в конкретній ситуації. Виходячи з цього визначення, можна задавати межі психологічної стійкості, які зводяться до потенційних можливостей людини та соціуму і об'єктивних вимог конкретної ситуації.

Людина не $є$ беззахисною перед негативним психологічним впливом, навіть в інформаційну епоху. Психіка людини має особливий механізм, певну здатність відновлюватися після психологічних травм і протистояти будь-якому впливу, який порушує її сталість, що і характеризує психологічну стійкість взагалі.

Формування уявлення про психологічну стійкість у вітчизняній і світовій психологічній науці відбувалося в контексті різних теоретико-методологічних підходів. Науковий інтерес до проблеми психологічної стійкості концентрувався переважно на пошуку корелятів емоційної стійкості з різними особистісними властивостями. Останнє десятиріччя ознаменувалося появою низки психологічних досліджень, метою яких стало безпосереднє вивчення захисного та адаптаційного потенціалу емоційної стійкості. Здійснюються спроби цілісного осмислення особистісних характеристик, відповідальних за успішну адаптацію і подолання людиною важких життєвих ситуацій. Однак з'явилися суттєві розбіжності у визначенні характеристики психологічної стійкості. Так, на думку І. Аршави, психологічна стійкість, насамперед, виявляється у здатності відновлювати позитивні психічні стани. У своєму дослідженні авторка узагальнює багатозначність уявлень про психологічну стійкість, спираючись на різні її визначення: стійкість як відсутність значних змін у часі; стійкість до стресів як здатність повертатися після порушення в початковий стан; стійкість як швидкість повернення в початковий стан після порушення тощо [7].

Емоційна стійкість $€$ і однією з найважливіших передумов успішного вирішення людиною їі основних життєвих задач [16] і фрактором збереження здоров'я, як психічного, так і фрізичного. Найбільше емоційною стійкістю маніпулюють перед різного роду виборами, підштовхуючи виборця до голосування під впливом емоцій, а не глибоких роздумів та оцінок пройденого. Нині емоційну стійкість вважають однією $з$ найважливіших детермінант успішності життєдіяльності людини в цілому, складовою частиною «емоційного інтелекту» (або емоційної розумності) людини, що забезпечує, зокрема, підтримування нею доброзичливих стосунків з оточуючими. Недарма емоційна стійкість фрігурує як один з п'яти «глобальних факторів» особистості у моделі «Велика п'ятірка», універсальність якої підтверджена на основі численних таксономічних досліджень, проведених для носіїв різних культур, у тому числі й української. У літературі з проблеми дослідження стресостійкості обговорюються можливості віднесення емоційної стійкості або до стабільних рис особистості, яка у такому разі повинна залишатися незмінною протягом усього життя, або до динамічних характеристик особистості, які можуть змінюватися 3 досвідом в процесі пристосування до складних умов діяльності. Емоційну стійкість визначають як: а) інтегративну властивість особистості; б) психічний стан (тривалий або оперативний), що сприяє (як у першому, так і в другому випадках) оптимізації (забезпеченню ефективності) діяльності і збереженню психічного і фрізичного здоров'я суб'єкта. Емоційна стійкість, як припускають дослідники, змінюється під впливом пристосування людини до екстремальних умов, проте успішність пристосування залежить від низки стійких особистісних характеристик, у тому числі від характеристик емоційності в структурі особистості, від мотиваційних і вольових характеристик, від стильових рис пізнавальної діяльності, пов'язаних з емоційністю [6].

В умовах непростого й динамічного життя людини в інформаційну епоху, під новим кутом доречно подивитись на традиційні уявлення про ії емоційну стійкість. Якщо традиційний погляд на ці процеси визначав емоційну стійкість як інтегративну властивість особистості, що характеризується взаємодією емоційних, вольових, інтелектуальних та мотиваційних компонентів психічної діяльності індивідуума, яке забезпечує успішне досягнення цілі в складному емотивному оточенні, сталість психічних та рухомих фрункцій в умовах емоційних впливів, співвідношення позитивних дій індивідуума у спокійному та в емоційному станах. То в нових посилених інформаційних умовах нинішнього людського життя до інтегрованої властивості компонентів психологічної стійкості слід додати й інформаційний компонент, що впливає на оптимальний варіант адаптаційних біохімічних, психологічних та фрізіологічних змін, які відбуваються в екстремальних емоційних умовах і забезпечують збереження доцільності поведінки і діяльності індивідуума на високому рівні.

Я. Амінєва вважає, що, ґрунтуючись на аналізі сучасних досліджень феномена емоційної стійкості, ми впевнено можемо констатувати наявність стресозахисного та адаптаційного потенціалу у ії структурі та розглядати вищеназвану індивідуально-психологічну характеристику в якості однієї з детермінант, що визначає ефективність діяльності у стресогенних умовах повсякденного життя [4].

О. Маклаков та Д. Леонтьєв для дослідження психологічної стійкості використовують поняття «особистісний адаптаційний потенціал». Це поняття, на їх думку, пов'язане зі стійкістю особистості до дії екстремальних факторів і описується через нервово-психічну стійкість, яка визначає стійкість до стресу; самооцінку особистості, яка забезпечує адекватність розуміння своїх можливостей; відчуття соціальної підтримки, що обумовлює почуття власної значущості для оточуючих; рівень конфоліктності особистості; досвід соціального спілкування. Всі перераховані характеристики автор вважає значущими при оцінці і прогнозі успішності адаптації до важких і екстремальних ситуацій, а також при оцінці швидкості відновлення психічної рівноваги [14].

Особистісний потенціал, згідно Д. Леонтьєву, є інтегральною характеристикою рівня особистісної зрілості, а головним феноменом особистісної зрілості і формою прояву особистісного потенціалу є саме феномен самодетермінації особистості. Особистісний потенціал відображає здатність подолання особистістю заданих обставин, в кінцевому рахунку, подолання особистістю самої себе, а також міру прикладених нею зусиль у ро- 
боті над собою і над обставинами свого життя. Однією зі специфічних форм прояву особистісного потенціалу $€$ подолання особистістю несприятливих умов її розвитку. Ці несприятливі умови можуть бути задані генетичними особливостями, соматичними захворюваннями, а можуть - зовнішніми несприятливими умовами, які можуть фратальним чином впливати на особистісний розвиток, але їх вплив може бути подолано, коли прямий зв'язок розірваний за рахунок введення в цю систему чинників додаткових вимірів на основі особистісного потенціалу [12].

Розвиваючи теоретичні підходи О. Маклакова та Д. Леонтьєва, доречно припустити, що всякий соціум також повинен мати свій психологічний потенціал, а в умовах інформаційного століття цей потенціал також буде мати потужну інформаційну складову, яка безпосередньо й впливає на психологічний потенціал. У свою чергу, Г. Нікифоров розглядає психологічну стійкість як складну якість особистості, яка, на його думку, являє собою синтез окремих якостей і здібностей, де об'єднуються врівноваженість, стійкість, стабільність і опірність [17]. Психологічну стійкість підтримують внутрішні (особистісні) та зовнішні (міжособистісна, соціальна підтримка) ресурси [10].

Опис психологічної стійкості як характеристики особистості $€$ в дослідженнях психологічної безпеки, що виявляється у взаємодії між окремими людьми або між групами осіб (К. В. Сельчінок, В. І. Слободчиков та ін.) і психологічної культури (Є. Фромм, К. О. Абульханова-Славська, В. С. Степін та ін.) як складової духовно-морального виховання [5].

Белюмов В. М., Костенко О. Р. під стійкістю розуміють здатність протистояти труднощам, зберігати віру в ситуаціях фррустрації. Урівноваженість - домірність сили реагування, активності поводження силі подразника, значенню події. Опірність - це здатність до опору тому, що обмежує волю поводження. Стійкість виявляється в подоланні труднощів як здатність зберігати віру в себе, бути впевненим у собі, своїх можливостях, як здатність до ефективної психічної саморегуляції [9].

Т. Рогачова, Г. Залевський, Т. Левицька до основних компонентів психологічної стійкості відносять динамічність як визначену психологічну складову для пересилення психологічної напруги, емоційність як суб'єктивну форму виразу потреби особистості, волю, інтелектуальні здібності особистості, включно із сукупністю розумових здібностей, самооцінку та професійну компетентність [19].

У зарубіжній психології особистісним чинникам стійкості приділяють менше уваги, пильніше розглядаючи тільки декілька головних, пов'язаних із функціонуванням особистості в соціальному середовищі. Так, Б. Бернард виокремлює чотири головні особистісні чинники стійкості, наведені нижче.

1. Соціальна компетентність (до якої належать чуйність, комунікабельність, емпатійність, дбайливість, співчуття, альтруїзм і здатність пробачати).

2. Здатність до вирішення проблем (здібності до планування, гнучкість, винахідливість, критичне мислення, інсайтне мислення).

3. Автономія (яка включає позитивну ідентичність, інфернальний локус контролю, ініціативність, самоефективність, майстерність, адаптивну дистанційованість від інших, опірність, самосвідомість і почуття гумору).
4. Усвідомлення мети і майбутнього (до якого належить мета-вказівка, орієнтація на успіх, мотивація досягнення, навчальна спрямованість, постійність, оптимізм, віра у світле майбутнє, почуття послідовності, духовність, сенс життя, креативність, розвинена уява) [1].

Феномен психологічної стійкості закордонні вчені рекомендують розглянути й по відношенню до національної еліти, в аспекті її стресостійкості. У цьому відношенні, вивчаючи різний вплив стресових подій на хворобу керівників, Сюзен Кобейса запропонувала поняття «Hardiness» [2].

Сучасні дослідження френомена емоційної стійкості вказують на наявність стресозахисного та адаптаційного потенціалу у її структурі. Традиційно дослідники розглядають «Hardiness» як життєстійкість у зв'язку 3 проблемами подолання стресу, адаптацією/дезадаптацією в суспільстві, фрізичним, психічним і соціальним здоров'ям. Тому доречно розглядати вищеназвану індивідуально-психологічну характеристику в якості однієї з детермінант, що визначає ефективність діяльності у стресогенних умовах повсякденного життя. Надалі поняття Hardiness отримало подальший розвиток в роботах Сальватора Мадді, де воно розглядається як інтегративна якість особистості, що $є$ показником психічного здоров'я людини [3].

У вітчизняній літературі прийнято перекладати «Hardiness» як «стійкість» або «жит-тєстійкість» (Д. О. Леонтьєв). Отже, "Hardiness" - витривалість, стійкість, сміливість, відвага, безстрашність, відповідно "hardy" - витривалий, стійкий, сміливий, відважний, зухвалий.

Таким чином, виявляти психологічну стійкість означає визначеним чином реагувати на зовнішні впливи, співставляти різні точки зору та вчинки людей, громадських та політичних діячів із своїми нормами та принципами, щоб успішно реалізувати свою лінію поведінки. Інформаційно-психологічна стійкість - це властивість особистості, окремими аспектами якої $€$ стійкість, урівноваженість, опірність. Вона дає змогу особистості протистояти життєвим труднощам, несприятливому тиску обставин, зберігати здоров'я і працездатність у різних випробуваннях, у тому числі й тих, що проявляються в інформаційно-психологічній ссрері людського буття

Стійкість - це комплексна

Висновки системна характеристика особистості, виражена шляхом об'єднання рівнів життя та діяльності людини. Такими рівнями стали стресостійкість, психологічна стійкість, психологічна безпека та психологічна культура. Психологічну стійкість можна характеризувати, як підсистему психологічної безпеки. Психологічна стійкість - це якість особистості, окремими аспектами якої $є$ стійкість, урівноваженість, опірність. Вона дає змогу особистостям протистояти життєвим труднощам, несприятливому тиску обставин, зберігати здоров'я і працездатність у різних випробуваннях.

Психологічна стійкість є складною і невід'ємною якістю особистості. У ній поєднаний цілий комплекс здатностей, широке коло різнорівневих явищ. Буття особистості різнопланове, що знаходить втілення в різних аспектах її психологічної стійкості. На передній план виходять три аспекти психологічної стійкості: стійкість, стабільність; урівноваженість, домірність; 
опірність (резистентність). Психологічна стійкість - це цілісна, інтегральна якість особистості, яка проявляється в здатності оптимально відображати дійсність в складних життєвих ситуаціях, готовність людини до дії в цих ситуаціях, здатність проживати важку життєву ситуацію без будь-якого збитку для себе, долати ії наслідки за допомогою способів, що вдосконалюють соціальну зрілість особистості.

Узагальнюючи огляд теоретичних положень щодо психологічної стійкості, можна сказати, що психологічна стійкість особистості пов'язана з постійним особистісним розвитком і характеризується гнучкістю, здатністю до аналізу і осмислення досвіду. Будучи інтегральною якістю особистості, окремими аспектами якої $є$ стійкість, врівноваженість, опірність, психологічна стійкість визначає здатність людини протистояти життєвим труднощам, несприятливого тиску обставин, зберігати при цьому працездатність і здатність освоювати новий досвід в різних ситуаціях. Низька психологічна стійкість породжує неприйняття нового, заперечення будь-яких аспектів своєї особистості, внутрішній або зовнішній опір.

В нових посилених інформаційних умовах нинішнього людського життя до інтегрованої властивості компонентів психологічної стійкості слід додати й інформаційний компонент, що впливає на оптимальний варіант адаптаційних біохімічних, психологічних та фізіологічних змін, які відбуваються в екстремальних емоційних умовах і забезпечують збереження доцільності поведінки і діяльності індивідуума на високому рівні. В інформаційну епоху однією з найхарактерніших особливостей сучасного життя $€$ ніщо інше, як підвищений інформаційно-психологічний вплив на людину, суспільство, державу. Тому, на думку автора, нині доречно говорити не стільки про психологічну стійкість, як про її нову якість - інформаційно-психологічну стійкість. Особливо інфрормаційно-психологічна стійкість необхідна у сфрері державного управління та публічного адміністрування. Властивість інформаційно-психологічної стійкості особистості фрормується у людини в процесі ії розвитку і не є генетично обумовленою.

\section{Література.}

1. Bernard B. Fostering Resiliency in Kids: Protective Factors in the Family, School and Community.Minneapolis : University of Minnesota, 1991. 22 p.

2. Kobasa, S. C. Stressful life events, personality, and health: An inquiry into hardiness. Journal of Per-sonality and Social Psychology, Vol. 37 (1), Jan 1979. P. 1-11.

3. Maddi, Salvatore R., Khoshaba, Deborah M. Hardiness and Mental Health. Journal of Personality Assessment, 1994 Oct, v 63 (n 2). P. 265-274.

4. Амінєва Я. Р. Емоційна стійкість особистості як одна з детермінант ефективного подолання складних життєвих ситуацій. Вісник ДНУ. Серія: Педагогіка $і$ психологія, 2012, Вип. 18, т. 20, № 9/1.

5. Андреєва Т. І. Допомога курцям у припиненні паління: практичне керівництво для працівників охорони здоров'я. Київ, 2002. 146 с.

6. Аршава І. Ф., Носенко Е. Л. Роль емоційної стійкості у збереженні здоров'я людини. URL: [iarshava@ mail.ru, enosenko2001@mail.ru]
7. Аршава, І. Ф., Носенко Е. Л. Аспекти імпліцитної діагностики емоційної стійкості людини: моногр. Дніпро: Вид-во ДНУ, 2008. 468 с.

8. Баландин М. М. Условия фоормирования психологической устойчивости у старшеклассников: автореф. канд. психол. н. Москва, 2003. 22 с.

9. Белюмов В. М., Костенко О. Р. Вред алкаголя, никотина и наркотиков. Київ, 1989. 192 с.

10. Запорожненко В. Г. Образ жизни и вредные привычки. Москва, 1984. 184 с.

11. Лентьев А. Н. Деятельность. Сознание. Личность. 2-е. изд. Москва: Политиздат, 1977.

12. Леонтьев Д. А. Личностное в личности: личностный потенциал как основа самодетерминации. Ученые записки кафредры общей психологии МГУ им. М. В. Ломоносова; под ред. Б. С. Братуся, Д. А. Леонтьева. Москва : Смысл, 2002. Вып. 1. С. 56-65.

13. Мазур Т. В., Лещенко М. Є., Орешета Ю. В., Інтегральна характеристика психологічної стійкості особистості у важких життєвих ситуаціях. Проблеми соціальної роботи: фрілософрія, психологія, соціологія № 1(9), 2017. С. 42.

14. Маклаков А. Г., Чермянин С. В. Психологическое прогнозирование в экстремальных условиях деятельности. Вестник Санкт-Петербургского Университета. 2009. Вып. 4 серия 12 декабрь 2009. C. $142-148$.

15. Мітина Л. М., Асмаковец Е. С. Ємоциональная гибкость учителя: психологическое содержание, диагностика, коррекція. Москва: МПСИ: ФЛИНТА, 2001. $192 \mathrm{c}$

16. Носенко Е. Л. Особистісні фрактори успішності вирішення людиною основних життєвих задач (у світлі сучасних теорій особистості): матеріали II Всеукр. психол. конгресу, присвяченого 110 річниці від дня народження Г. С. Костюка (м. Київ, 19-20 квітня 2010). Київ: ДП «Інфрормаційно-аналітичне агентство», 2010. Т. 1. С. 273-278.

17. Психология здоровья: учебник для вузов / под ред. Г. С. Никифорова. СПб.: ИТЕР, 2003. 607 с.

18. Ребер, А. Большой толковый психологический словарь: в 2 т. Москва: Вече, 2003. Т. 1. 559 с.

19. Рогачева Т. В., Залевский Г. В., Левицкая Т. Е., Психология экстремальных ситуаций и состояний: учеб. пособие. Томск: Издательский Дом ТГУ, 2015. $276 \mathrm{c}$.

20. Чудновский В. Є. Нравственная устойчивость личности: Психол. Исследования. / Научно-исслед. Институт общ. и пед. Психологии АПН СССР. Москва: Педагогика, 1981. 208 с. 